Angelo Azzi

Summary A role of oxidative stress in atherosclerosis lies on experimental results carried out in vitro and in animal models. In humans, the supplementation with the antioxidant vitamin $\mathrm{E}$ has given in some cases supportive results and in others no effects. From in vitro studies, a large amount of data has shown that $\alpha$-tocopherol (the major component of vitamin E) regulates key events in the cellular pathogenesis of atherosclerosis.

Professor Angelo Azzi ( $(\mathbb{})$

Institut für Biochemie

und Molekularbiologie

Universität Bern

Bühlstrasse 28

3012 Bern, Switzerland

Tel.: + 4131-631/4131

Fax: +4131-631/3737

E-Mail: angelo.azzi@mci.unibe.ch

\title{
The role of $\alpha$-tocopherol in preventing disease
}

We first described the inhibition of protein kinase $\mathrm{C}$ (PKC) activity by $\alpha$-tocopherol to be at the basis of the vascular smooth muscle cell growth inhibition by this compound. Subsequently, PKC was recognized to be the target of $\alpha$-tocopherol in different cell types, including monocytes, macrophages, neutrophils, fibroblasts and mesangial cells. Inhibiting the activity of protein kinase $\mathrm{C}$ by $\alpha$-tocopherol results in different events in different cell types: inhibition of platelet aggregation, of nitric oxide production in endothelial cells, of superoxide production in neutrophils and macrophages as well as impairment of smooth muscle cell proliferation. Adhesion molecule expression and inflammatory cell cytokine production are also influenced by $\alpha$-toco- pherol. Scavenger receptors, particularly important in the formation of atherosclerotic foam cells, are also modulated by $\alpha$-tocopherol. The oxidized LDL scavenger receptors SR-A and CD36 are down regulated at the transcriptional level by $\alpha$-tocopherol. The relevance of CD36 expression in the onset of atherosclerosis has been indicated by the protection against atherosclerosis by CD36 knockout mice. In conclusion, the effect of $\alpha$-tocopherol against atherosclerosis is not due only to the prevention of LDL oxidation but also to the down regulation of the scavenger receptor CD36 and to the inhibition of PKC activity.

Key words $\alpha$-tocopherol atherosclerosis - vitamin E metabolism - CHD

\section{Atherosclerosis protection by vitamin $\mathrm{E}$ is seen in several animal studies}

Hypercholesterolemia can lead to enhanced plasma oxidized LDL concentration and impaired endothelial function. Vitamin E can prevent some of these events by a number of mechanisms. In cholesterol-fed rabbits $[1,2]$, vitamin $\mathrm{E}$ fully prevented cholesterol-induced atherosclerotic lesions. In Watanabe rabbits, vitamin $\mathrm{E}$ added to the food inhibited LDL oxidation and $\stackrel{8}{a}$ caused a reduction of the atherosclerotic area [3]. In contrast, New Zealand White rabbits, fed a $1 \%$ cholesterol diet and $10.000 \mathrm{IU} / \mathrm{kg} \alpha$-tocopheryl acetate, showed significantly more intima atherosclerotic proliferation [4].

In atherosclerosis-susceptible apolipoprotein $\mathrm{E}$ knockout mice, vitamin E deficiency, created by disruption of the $\alpha$-tocopherol transfer protein gene, increased the severity of atherosclerotic lesions in the proximal aorta [5].

In a different study [6], male monkeys were given natural vitamin E during 3 years and their carotid arteries thickness was monitored by ultrasound analysis. Vitamin $\mathrm{E}$ was found to significantly inhibit the progression of the disease in both cases when the animals received the treatment at the beginning of the experiment, and when atherosclerosis had already started. 
The effect of $\alpha$-tocopherol in animals may not be only due to its antioxidant properties. Probucol, a powerful inhibitor of atherosclerosis in a number of animal models actively increased atherogenesis in LDLR-/mice, even though it provided a very strong antioxidant protection of LDL [7]. Reduction of atherosclerosis by Probucol observed in some animal models is thus due to intracellular events which are absent in mice or to differences in the metabolism of probucol. A dissociation of atherogenesis from aortic accumulation of lipid hydro(pero)xides in Watanabe heritable hyperlipidemic rabbits has been also shown [8].

An extensive literature coverage of the subject is not appropriate at this time, but the cited studies show that antioxidants may be proatherogenic or antiatherogenic in different animal models and that LDL oxidation does not constantly correlate with atherogenic events.

\section{Vitamin E protects humans against a number of disorders}

Vitamin E deficiency is associated with a precise ailment: cerebellar ataxia. Mutations of the $\alpha$-TTP gene lead to reduced $\alpha$-tocopherol concentrations in plasma and tissues that ultimately lead to a severe syndrome named ataxia with vitamin E deficiency (AVED) [9]. Following a vitamin $\mathrm{E}$ therapy, some of the neurological symptoms of AVED may regress in some patients [10, 11]. Furthermore, vitamin $\mathrm{E}$ supplementation has shown beneficial effects for a number of disorders, in particular atherosclerosis, ischemic heart disease, and development of different types of cancer [12-14]. It appears evident that the biological role of vitamin $\mathrm{E}$ needs to be rediscussed, since its simple antioxidant function is not sufficient to explain all the effects shown by the molecule.

\section{Protection against human atherosclerosis has been observed in subjects taking high vitamin $E$ quantities with the diet}

A study of 16 European populations showed a strong inverse correlation between plasma concentrations of vitamin $\mathrm{E}$ and the risk of cardiovascular disease death [15].

In a case control study, the EURAMIC, $\alpha$-tocopherol and $\beta$-carotene had no protective effect [16] although a large prospective cohort study (Nurses' Health Study) revealed that those who obtained vitamin $\mathrm{E}$ from supplements had a relative risk of nonfatal myocardial infarction or death from coronary disease of 0.54 [17].

\section{Arterial imaging studies}

The arterial wall thickness (IMT) can be measured noninvasively by ultrasound and consequently the extent of atherosclerosis at early, sub-clinical stages can be evaluated $[18,19]$. In the EVA trial it was shown that higher red blood cell vitamin $\mathrm{E}$ was correlated with lower thickening of the arterial wall [20].

Also in the Kuopio Ischemic Heart Disease Study [21] a very significant inverse correlation between the progression of carotid artery narrowing and vitamin $\mathrm{E}$ plasma levels was found. The Antioxidant Supplementation in Atherosclerosis Prevention study (ASAP) has analyzed the effect of vitamin $\mathrm{E}$ and $\mathrm{C}$ on 3-year progression of carotid atherosclerosis [22]. Atherosclerotic progression, measured by IMT, was reduced by $74 \%$ in the male population receiving both vitamins. No effect on the arterial wall thickness has been found in the female group.

Using data from the Cholesterol Lowering Atherosclerosis Study (CLAS) [23], less carotid IMT progression was found for high supplementary vitamin E users when compared with low vitamin E users [24]. However, in the Study to Evaluate Carotid Ultrasound changes in patients treated with Ramipril and vitamin E (SECURE), showed no differences in atherosclerosis progression rates between patients on vitamin $\mathrm{E}$ and those on placebo, whereas treatment with ramipril showed a beneficial effect [25].

Although it appears from the majority of this type of studies that vitamin E protects against carotid thickening, more complex results are provided by the SECURE trial and by the ASAP trial.

\section{Controlled intervention trials}

The classical Alpha-Tocopherol beta Carotene (ATBC) trial, the Linxian China trial, the Cambridge Heart Antioxidant Study (CHAOS) in England, and Gruppo Italiano per lo Studio della Sopravvivenza nell' Infarto Miocardico (GISSI) in Italy have given contrasting results.

The CHAOS study, a secondary prevention trial that enrolled subjects with established heart disease [26], showed that vitamin $\mathrm{E}$ administration resulted in $77 \%$ reduction in the risk for nonfatal myocardial infarction. However, the results of the GISSI trial (11.324 patients who had survived a myocardial infarction) did not reach statistical significance for the group given vitamin E [27, 28]. A re-evaluation of the data [29-31] suggested more recently that cardiovascular mortality was significantly reduced by vitamin $\mathrm{E}$ in GISSI and the effect on overall survival showed a very favorable trend. The Linxian China Study tested four micronutrients on overall mortality and cancer mortality [32]. The subjects' small but 
significant reductions in total and cancer mortality were observed in subjects receiving $\beta$-carotene, vitamin $\mathrm{E}$, and selenium.

The ATBC trial tested the effects of vitamin E, $\beta$ carotene, and both micronutrients together in heavy smokers [33]. The subjects on vitamin E experienced $32 \%$ lower risk of prostate cancer and a $41 \%$ lower mortality from prostate cancer [34]. A statistically significant benefit was not found for either micronutrient on heart disease [35]. It should be noticed that, like the Linxian study, the ATBC trial used a much smaller dose of syntetic vitamin E than the CHAOS and the GISSI studies.

In the Heart Outcomes Prevention Evaluation study (HOPE) [36], primary outcomes, defined as myocardial infarction, stroke or cardiovascular disease death, did not differ after vitamin $\mathrm{E}$ administration.

In the Secondary Prevention with Antioxidants of Cardiovascular Disease in Endstage Renal Disease (SPACE) [37], a $46 \%$ reduction was attained in the primary endpoint (myocardial infarction, ischemic stroke, peripheral vascular disease, and unstable angina.

The MRC/BHF Heart Protection Study Collaborative Group 2001 has carried out a randomized trial of cholesterol-lowering therapy and of antioxidant vitamins in 20.536 people at increased risk of coronary heart disease death. They have shown that statins can reduce the risk of heart attack or stroke by up to one third but vitamin $\mathrm{C}$ and/or vitamin $\mathrm{E}$ were without evident benefit. [Congress of the American Heart Association Scientific Sessions, 2001, November 11-14. Anaheim, California].

Of the most important intervention studies, CHAOS and SPACE are consistent with each other and a careful analysis of the GISSI study reveals that $\alpha$-tocopherol supplementation resulted in significant effects. However the HOPE and the MRC/BHF Heart Protection Study Collaborative Group have given decisive negative outcomes. It is clear that the selection of the population, the amount of tocopherol, the ability of being absorbed, the genotypic and nutritional aspects of the population studied may be important in the understanding of the present discrepancies.

\section{Selective uptake of vitamin E into the body}

Vitamin $\mathrm{E}$ is taken up together with dietary lipids in the proximal part of the intestine. The tocopherols are reassembled together with lipids and apolipoproteins into chylomicrons. Chylomicron lipolysis, facilitated by lipoprotein lipase, allows part of vitamin $\mathrm{E}$ to be distributed to tissues [38]. Chylomicron remnants deliver the other part of $\alpha$-tocopherol to the liver, where, specifically recognized by the $32 \mathrm{kDa} \alpha$-tocopherol transfer protein $(\alpha-T T P)$, is incorporated into VLDL, and then transported and delivered to peripheral cells
[39]. The plasma phospholipid transfer protein (PLTP) facilitates the exchange of tocopherol between LDL and HDL [40].

The scavenger receptor SR-B1 promotes the uptake of HDL tocopherol into type II pneumocytes [41], into cells constituting the blood brain barrier [42] and into the liver, where it is again specifically recognized by $\alpha$-TTP, recycled and secreted in VLDL [43]. $\alpha$-TTP gene mutation results in low serum and cell $\alpha$-tocopherol. Thus, in the two factors needed for realizing an adequate level of $\alpha$-tocopherol in the body are dietary availability and the expression of liver $\alpha$-TTP. Relative affinities of tocopherol analogs for $\alpha$-TTP, calculated from the degree of competition for the $\alpha$ form, are as follows: $\alpha$-tocopherol, $100 \%$, $\beta$-tocopherol, $38 \%$; $\delta$-tocopherol, $9 \%$; ä-tocopherol, $2 \%$; $\alpha$-tocopherol acetate, $2 \%$; $\alpha$-tocopherol quinone, $2 \%$ [44]. Some of the eight different side-chain isomers of racemic tocopherol are excluded from the plasma and secreted with the bile $[45,46]$.

\section{Tocopherol binding proteins in tissues}

$\alpha$-TTP is expressed in the liver, in some parts of the brain [47], in the retina [48], lymphocytes and fibroblasts [49] as well as in the labyrinthine trophoblast region of the placenta. The latter may play an important role in supplying the vitamin to the fetus, and explains the fetal resorption occurring in rats fed a vitamin $\mathrm{E}$ deficient diet [50].

It is still unclear how many other $\alpha$-tocopherol binding proteins exist, and which mechanism regulates $\alpha$-tocopherol transfer and its concentration in peripheral cells. Recently, a novel tocopherol binding protein has been identified, the $46 \mathrm{kDa}$ tocopherol associated protein (TAP) [51]. Ubiquitously expressed, TAP may be specifically involved in the intracellular transport of tocopherol, for example between membrane compartments and the plasma membrane, similar to the yeast secretory protein (sec14). Being provided with GTPase activity TAP may regulate functions, such as phospholipid/tocopherol signalling, phospholipid/tocopherol secretion or adjusting the tocopherol composition of membranes.

A $15 \mathrm{kDa}$ tocopherol binding protein (TBP), which preferentially binds $\alpha$-tocopherol, may be responsible for intracellular distribution of $\alpha$-tocopherol $[52,53]$.

\section{Molecular properties of $\alpha$-tocopherol}

\section{Antioxidant and non-antioxidant functions}

It is common believe that phenolic compounds like vitamin $\mathrm{E}$ exert only a protective role against free radical damage and that vitamin $\mathrm{E}$ is the major hydrophobic 
chain-breaking antioxidant that prevents the propagation of free radical reactions in membranes and lipoproteins.

The antioxidant properties of vitamin $\mathrm{E}$ are well known [54] especially in connection with the prevention of LDL oxidation [55] although the correlation between LDL oxidation and atherosclerosis is not always evident $[56,57]$. Alternative studies have suggested that $\alpha$-tocopherol protection against LDL oxidation may be secondary to the inhibition of protein kinase $\mathrm{C}(\mathrm{PKC})$. This enzyme is responsible for triggering the release of reactive oxygen species with consequent lipid oxidation [58, 59].

The non-antioxidant properties of tocopherol have been indicated by several experiments in which the four tocopherol analogues had effects that could not be correlated with their anti-oxidant capacity. Furthermore, the selective uptake and transport of $\alpha$-tocopherol appears to represent the evolutionary selection of a molecule with unique functions not shared by other antioxidants.

\section{Effects of $\alpha$-tocopherol at cellular level}

PKC inhibition was found to be at the basis of the vascular smooth muscle cell growth arrest induced by $\alpha$-tocopherol [60-62]. It occurs at concentrations of $\alpha$-tocopherol close to those measured in healthy adults [63]. $\beta$-Tocopherol, per se ineffective, prevents the inhibitory effect of $\alpha$-tocopherol. The mechanism involved is not related to the radical scavenging properties of these two molecules, which are essentially equal [64]. This phenomenon has been confirmed in a number of different cell types, including monocytes, macrophages, neutrophils, fibroblasts and mesangial cells [65-72]. $\alpha$-Tocopherol, but not $\beta$-tocopherol, inhibits thrombin-induced PKC activation and endothelin secretion in endothelial cells [73]. It inhibits also PKC dependent phosphorylation and translocation of the cytosolic factor p47(phox) in monocytes, with consequent impairment of the NADPH-oxidase assembly and of superoxide production [58].

In vitro studies have shown that inhibition of recombinant PKC by $\alpha$-tocopherol is not caused by a tocopherol-protein interaction. In addition, $\alpha$-tocopherol does not inhibit PKC expression. Inhibition of PKC activity by $\alpha$-tocopherol occurs at the cellular level by producing dephosphorylation of the enzyme, whereby $\beta$-tocopherol is much less potent [74]. Dephosphorylation of PKC occurs via the protein phosphatase $\mathrm{PP}_{2} \mathrm{~A}$, which has been found to be activated by the treatment with $\alpha$-tocopherol [74-76].

\section{Transcriptional regulation by $\alpha$-tocopherol}

Upregulation of $\alpha$-tropomyosin expression by $\alpha$-tocopherol, and not by $\beta$-tocopherol occurs via a non-antioxidant mechanism $[77,78]$. In human skin fibroblasts the age-dependent increase of collagenase expression can be reduced by $\alpha$-tocopherol [79]. The liver $\alpha$-tocopherol transfer protein ( $\alpha$ TTP) and its mRNA are modulated by dietary vitamin $\mathrm{E}$ [80]. Scavenger receptors are particularly important in the formation of atherosclerotic foam cells [81] and disruption of CD36 protects against atherosclerotic lesions. In smooth muscle cells and monocytes/macrophages, the oxidized LDL scavenger receptors SR-A and CD36 are down regulated at the transcriptional level by $\alpha$-tocopherol but not by $\beta$ tocopherol [82-84].

\section{Inhibition of monocyte-endothelial adhesion}

$\alpha$-Tocopherol enrichment of monocytes, as well as neutrophils, decreases adhesion to human endothelial cells both in vivo and in vitro $[85,86]$ and depends on the expression of adhesion molecules [87-89].

\section{Inhibition of platelet adhesion and aggregation}

$\alpha$-Tocopherol inhibits aggregation of human platelets by a PKC-dependent mechanism both in vitro and in vivo $[68,90]$ and delays intra-arterial thrombus formation [91]. The studies reported above are consistent with the conclusions of Iuliano et al. [92] that circulating LDL accumulates in human atherosclerotic plaques and that such accumulation by macrophages is prevented by $\alpha$ tocopherol in vivo. The protection by $\alpha$-tocopherol may not be due only to the prevention of LDL oxidation, but also to the down regulation of the scavenger receptor CD36 and to the inhibition of PKC activity.

Despite a general agreement on the $\alpha$-tocopherol inhibitory action at PKC level, the expression of several genes, such as CD36 [83], SR class A [93], collagenase [79], and ICAM-1 [88], appears to be regulated by $\alpha$-tocopherol in a PKC independent way. Furthermore, a number of observations, such as PP2A [74] and diacylglycerol kinase [94] activation, 5-lipoxygenase [95] (Jialal et al. 2001) and cyclooxygenase (Wu et al. 2001) inhibition, still lack a mechanistic explanation.

\section{Conclusions}

From the study reported above three relevant conclusions can be derived. 1) It seems improbable that the effects of $\alpha$-tocopherol, relevant to the protection against atherosclerosis, as described at a biomolecular and ani- 
mal level, do not have a counterpart in the prevention of the human pathology. 2) The basis for the contradictory results obtained by similar clinical trials, carried out in different countries and by different research groups, is still obscure. 3) More adequate trial conditions on se- lected populations are needed to see protective effects of $\alpha$-tocopherol against human atherosclerosis.

Acknowledgments The studies reported here have been supported by the Swiss National Science Foundation, by the Foundation for Nutrition in Switzerland and from Bayer Vital.

\section{References}

1. Ozer NK, Sirikci O, Taha S, San T, Moser U, Azzi A (1998) Effect of vitamin E and probucol on dietary cholesterol-induced atherosclerosis in rabbits. Free Radic Biol Med 24:226-233

2. Ribeiro Jorge PA, Neyra LC, Ozaki RM, Almeida E de (1998) Improvement in the endothelium-dependent relaxation in hypercholesterolemic rabbits treated with vitamin E. Atherosclerosis 140: 333-339

3. Williams MA, Belcaro G, Szendro G, Nicolaides AN (1992) Duplex scanning evaluation of internal carotid stenosis. Improved detection of early lesions. Panminerva Med 34:49-54

4. Keaney JF Jr, Gaziano JM, Xu A, Frei B, Curran-Celentano J, Shwaery GT, Loscalzo J, Vita JA (1994) Low-dose alpha-tocopherol improves and highdose alpha-tocopherol worsens endothelial vasodilator function in cholesterol-fed rabbits. J Clin Invest 93: 844-851

5. Terasawa Y, Ladha Z, Leonard SW, Morrow JD, Newland D, Sanan D, Packer L, Traber MG, Farese RV Jr (2000) Increased atherosclerosis in hyperlipidemic mice deficient in alpha-tocopherol transfer protein and vitamin E. Proc Natl Acad Sci USA 97:13830-13834

6. Verlangieri AJ, Bush MJ (1992) Effects of d-alpha-tocopherol supplementation on experimentally induced primate atherosclerosis. J Am Coll Nutr 11:131-138

7. Benson GM, Schiffelers R, Nicols C, Latcham J, Vidgeon-Hart M, Toseland CD, Suckling KE, Groot PH (1998) Effect of probucol on serum lipids, atherosclerosis and toxicology in fat-fed LDL receptor deficient mice. Atherosclerosis 141:237-247

8. Witting PK, Mohr D, Stocker R (1999) Assessment of prooxidant activity of vitamin $\mathrm{E}$ in human low-density lipoprotein and plasma. Methods Enzymol 299:362-375

9. Ben Hamida C, Doerflinger N, Belal S, Linder C, Reutenauer L, Dib C, Gyapay G, Vignal A, Le Paslier D, Cohen D, et al. (1993) Localization of Friedreich ataxia phenotype with selective vitamin $\mathrm{E}$ deficiency to chromosome $8 \mathrm{q}$ by homozygosity mapping (see comments). Nat Genet 5:95-200
10. Benomar A, Yahyaoui M, Marzouki N, Birouk N, Bouslam N, Belaidi H, Amarti A, Ouazzani R, Chkili T (1999) Vitamin E deficiency ataxia associated with adenoma. J Neurol Sci 162:97-101

11. Labauge P, Cavalier L, Ichalalene L, Castelnovo G (1998) Friedreich's ataxia and hereditary vitamin $\mathrm{E}$ deficiency. Case study. Rev Neurol (Paris) 154: 339-341

12. Keaney JF Jr, Simon DI, Freedman JE (1999) Vitamin E and vascular homeostasis: implications for atherosclerosis. Faseb J 13:965-975

13. Pratico D, Tangirala RK, Rader DJ, Rokach J, FitzGerald GA (1998) Vitamin $\mathrm{E}$ suppresses isoprostane generation in vivo and reduces atherosclerosis in ApoE-deficient mice. Nat Med 4: 1189-1192

14. Sigounas G, Anagnostou A, Steiner M (1997) Dl-alpha-tocopherol induces apoptosis in erythroleukemia, prostate, and breast cancer cells. Nutr Cancer 28:30-35

15. Gey KF, Moser UK, Jordan P, Stahelin HB, Eichholzer M, Ludin E (1993) Increased risk of cardiovascular disease at suboptimal plasma concentrations of essential antioxidants: an epidemiological update with special attention to carotene and vitamin C. Am J Clin Nutr 57:787S-797S

16. Kardinaal AF, Kok FJ, Ringstad J, Gomez-Aracena J, Mazaev VP, Kohlmeier L, Martin BC, Aro A, Kark JD, Delgado-Rodriguez M, et al. (1993) Antioxidants in adipose tissue and risk of myocardial infarction: the EURAMIC Study. Lancet 342:1379-1384

17. Stampfer MJ, Hennekens $\mathrm{CH}$, Manson JE, Colditz GA, Rosner B, Willett WC (1993) Vitamin E consumption and the risk of coronary disease in women. $\mathrm{N}$ Engl J Med 328:1444-1449

18. Hodis HN, Mack WJ, Barth J (1996) Carotid intima-media thickness as a surrogate end point for coronary artery disease. Circulation 94:2311-2312

19. Selzer RH, Hodis HN, Kwong-Fu H, Mack WJ, Lee PL, Liu CR, Liu CH (1994) Evaluation of computerized edge tracking for quantifying intima-media thickness of the common carotid artery from B-mode ultrasound images. Atherosclerosis 111:1-11
20. Bonithon-Kopp C, Coudray C, Berr C, Touboul PJ, Feve JM, Favier A, Ducimetiere P (1997) Combined effects of lipid peroxidation and antioxidant status on carotid atherosclerosis in a population aged 59-71 y: The EVA Study. Etude sur le Vieillisement Arteriel. Am J Clin Nutr 65:121-127

21. Salonen JT, Salonen R (1993) Ultrasound B-mode imaging in observational studies of atherosclerotic progression. Circulation 87:II56-65

22. Salonen JT, Nyyssonen K, Salonen R, Lakka HM, Kaikkonen J, PorkkalaSarataho E, Voutilainen S, Lakka TA, Rissanen T, Leskinen L, et al. (2000) Antioxidant Supplementation in Atherosclerosis Prevention (ASAP) study: a randomized trial of the effect of vitamins $\mathrm{E}$ and $\mathrm{C}$ on 3-year progression of carotid atherosclerosis. J Intern Med 248:377-386

23. Blankenhorn DH, Johnson RL, Nessim SA, Azen SP, Sanmarco ME, Selzer, RH (1987) The Cholesterol Lowering Atherosclerosis Study (CLAS): design, methods, and baseline results. Control Clin Trials 8:356-387

24. Azen SP, Qian D, Mack WJ, Sevanian A, Selzer RH, Liu CR, Liu CH, Hodis HN (1996) Effect of supplementary antioxidant vitamin intake on carotid arterial wall intima-media thickness in a controlled clinical trial of cholesterol lowering. Circulation 94:2369-2372

25. Lonn E, Yusuf S, Dzavik V, Doris C, Yi Q, Smith S, Moore-Cox A, Bosch J, Riley W, Teo K (2001) Effects of ramipril and vitamin $\mathrm{E}$ on atherosclerosis: the study to evaluate carotid ultrasound changes in patients treated with ramipril and vitamin E (SECURE). Circulation 103: 919-925

26. Stephens NG, Parsons A, Schofield PM, Kelly F, Cheeseman K, Mitchinson MJ (1996) Randomised controlled trial of vitamin $\mathrm{E}$ in patients with coronary disease: Cambridge Heart Antioxidant Study (CHAOS). Lancet 347:781-786

27. Brown M (1999) Do vitamin E and fish oil protect against ischaemic heart disease? Lancet 354:441-442

28. Marchioli R (1999) Antioxidant vitamins and prevention of cardiovascular disease: laboratory, epidemiological and clinical trial data. Pharmacol Res $40: 227-238$ 
29. Jialal I, Devaraj S, Huet BA, Traber M (1999) GISSI-Prevenzione trial. Lancet 354:1554; discussion:1556-1557

30. Ng W, Tse HF, Lau CP (1999) GISSI-Prevenzione trial. Lancet 354:1555-1556; discussion:1556-1557

31. Salen P, de Lorgeril M (1999) GISSI-Prevenzione trial. Lancet 354:1555; discussion:1556-1557

32. Blot, WJ, Li JY, Taylor PR, Guo W, Dawsey S, Wang GQ, Yang CS, Zheng SF, Gail M, Li GY, et al. (1993) Nutrition intervention trials in Linxian, China: supplementation with specific vitamin/ mineral combinations, cancer incidence, and disease-specific mortality in the general population. J Natl Cancer Inst 85:1483-1492

33. Albanes D, Heinonen OP, Taylor PR, Virtamo J, Edwards BK, Rautalahti M, Hartman AM, Palmgren J, Freedman LS, Haapakoski J, et al. (1996) Alpha-Tocopherol and beta-carotene supplements and lung cancer incidence in the alpha-tocopherol, beta-carotene cancer prevention study: effects of base-line characteristics and study compliance. J Natl Cancer Inst 88:1560-1570

34. Heinonen OP, Albanes D, Virtamo J, Taylor PR, Huttunen JK, Hartman AM, Haapakoski J, Malila N, Rautalahti M, Ripatti S, et al. (1998) Prostate cancer and supplementation with alpha-tocopherol and beta-carotene: incidence and mortality in a controlled trial. J Natl Cancer Inst 90:440-446

35. Virtamo J, Rapola JM, Ripatti S, Heinonen OP, Taylor PR, Albanes D, Huttunen JK (1998) Effect of vitamin E and beta carotene on the incidence of primary nonfatal myocardial infarction and fatal coronary heart disease. Arch Intern Med 158:668-675

36. Yusuf S, Dagenais G, Pogue J, Bosch J, Sleight P (2000) Vitamin E supplementation and cardiovascular events in high-risk patients. The Heart Outcomes Prevention Evaluation Study Investigators. N Engl J Med 342:154-160

37. Boaz M, Smetana S, Weinstein T, Matas Z, Gafter U, Iaina A, Knecht A, Weissgarten Y, Brunner D, Fainaru M, Green MS (2000) Secondary prevention with antioxidants of cardiovascular disease in endstage renal disease (SPACE): randomised placebo-controlled trial (In Process Citation). Lancet 356: 1213-1218

38. Sattler W, Levak-Frank S, Radner H, Kostner GM, Zechner R (1996) Musclespecific overexpression of lipoprotein lipase in transgenic mice results in increased alpha-tocopherol levels in skeletal muscle. Biochem J 318:15-19

39. Behrens WA, Thompson JN, Madere R (1982) Distribution of alpha-tocopherol in human plasma lipoproteins. Am J Clin Nutr 35:691-696
40. Kostner GM, Oettl K, Jauhiainen M, Ehnholm C, Esterbauer H, Dieplinger $\mathrm{H}$ (1995) Human plasma phospholipid transfer protein accelerates exchange/ transfer of alpha-tocopherol between lipoproteins and cells. Biochem J 305: 659-667

41. Kolleck I, Schlame M, Fechner H, Looman AC, Wissel H, Rustow B (1999) $\mathrm{HDL}$ is the major source of vitamin $\mathrm{E}$ for type II pneumocytes. Free Radic Biol Med 27:882-890

42. Goti D, Hrzenjak A, Levak-Frank S, Frank S, van Der Westhuyzen DR, Malle E, Sattler W (2001) Scavenger receptor class $B$, type $I$ is expressed in porcine brain capillary endothelial cells and contributes to selective uptake of HDLassociated vitamin E. J Neurochem 76: 498-508

43. Goti D, Reicher H, Malle E, Kostner GM, Panzenboeck U, Sattler W (1998) Highdensity lipoprotein (HDL3)-associated alpha-tocopherol is taken up by HepG2 cells via the selective uptake pathway and resecreted with endogenously synthesized apo-lipoprotein B-rich lipoprotein particles. Biochem J 332: 57-65

44. Hosomi A, Arita M, Sato Y, Kiyose C, Ueda $\mathrm{T}$, Igarashi $\mathrm{O}$, Arai $\mathrm{H}$, Inoue $\mathrm{K}$ (1997) Affinity for alpha-tocopherol transfer protein as a determinant of the biological activities of vitamin $\mathrm{E}$ analogs. FEBS Lett 409:105-108

45. Traber MG, Kayden HJ (1989) Alpha-tocopherol as compared with gamma-tocopherol is preferentially secreted in human lipoproteins. Ann N Y Acad Sci 570:95-108

46. Traber MG, Kayden HJ (1989) Preferential incorporation of alpha-tocopherol vs gamma-tocopherol in human lipoproteins. Am J Clin Nutr 49:517-526

47. Copp RP, Wisniewski T, Hentati F, Larnaout A, Ben Hamida M, Kayden H J (1999) Localization of alpha-tocopherol transfer protein in the brains of patients with ataxia with vitamin $\mathrm{E}$ deficiency and other oxidative stress related neurodegenerative disorders. Brain Res 822:80-87

48. Yokota T, Shiojiri T, Gotoda T, Arita M, Arai H, Ohga T, Kanda T, Suzuki J, Imai T, Matsumoto H, etal. (1997) Friedreich-like ataxia with retinitis pigmentosa caused by the His101Gln mutation of the alpha-tocopherol transfer protein gene. Ann Neurol 41:826-832

49. Tamaru Y, Hirano M, Kusaka H, Ito H, Imai T, Ueno S (1997) Alpha-Tocopherol transfer protein gene: exon skipping of all transcripts causes ataxia. Neurology 49:584-588
50. Jishage $\mathrm{K}$, Arita $\mathrm{M}$, Igarashi $\mathrm{K}$, Iwata $\mathrm{T}$, Watanabe M, Ogawa M, Ueda O, Kamada N, Inoue K, Arai H, Suzuki H (2001) Alpha-tocopherol transfer protein is important for the normal development of placental labyrinthine trophoblasts in mice. J Biol Chem 276: 1669-1672

51. Zimmer S, Stocker A, Sarbolouki MN, Spycher SE, Sassoon J, Azzi A (2000) A novel human tocopherol-associated protein: cloning, in vitro expression, and characterization. J Biol Chem 275: 25672-25680

52. Dutta-Roy AK, Gordon MJ, Leishman DJ, Paterson BJ, Duthie GG, James WP (1993) Purification and partial characterisation of an alpha-tocopherol-binding protein from rabbit heart cytosol. Mol Cell Biochem 123:139-144

53. Dutta-Roy AK, Leishman DJ, Gordon MJ, Campbell FM, Duthie GG (1993) Identification of a low molecular mass (14.2 kDa) alpha-tocopherol-binding protein in the cytosol of rat liver and heart. Biochem Biophys Res Commun 196:1108-1112

54. Packer L, Weber SU, Rimbach G (2001) Molecular aspects of alpha-tocotrienol antioxidant action and cell signalling. J Nutrition 131:369S-373S

55. Esterbauer H, Schmidt R, Hayn $M$ (1997) Relationships among oxidation of low-density lipoprotein, antioxidant protection, and atherosclerosis. Adv Pharmacol 38:425-456

56. Perugini C, Bagnati M, Cau C, Bordone R, Paffoni P, Re R, Zoppis E, Albano E, Bellomo G (2000) Distribution of lipidsoluble antioxidants in lipoproteins from healthy subjects. II. Effects of in vivo supplementation with alpha-tocopherol. Pharmacol Res 41:67-74

57. Perugini C, Bagnati M, Cau C, Bordone R, Zoppis E, Paffoni P, Re R, Albano E, Bellomo G (2000) Distribution of lipidsoluble antioxidants in lipoproteins from healthy subjects. I. Correlation with plasma antioxidant levels and composition of lipoproteins. Pharmacol Res 41:55-65

58. Cachia O, Benna JE, Pedruzzi E, Descomps B, Gougerot-Pocidalo MA, Leger CL (1998) Alpha-tocopherol inhibits the respiratory burst in human monocytes. Attenuation of p47(phox) membrane translocation and phosphorylation. J Biol Chem 273:32801-32805

59. Devaraj S, Li D, Jialal I (1996) The effects of alpha tocopherol supplementation on monocyte function. Decreased lipid oxidation, interleukin 1 beta secretion, and monocyte adhesion to endothelium. J Clin Invest 98:756-763 
60. Boscoboinik D, Szewczyk A, Azzi A (1991a) Alpha-tocopherol (vitamin E) regulates vascular smooth muscle cell proliferation and protein kinase $\mathrm{C}$ activity. Arch Biochem Biophys 286: 264-269

61. Boscoboinik D, Szewczyk A, Hensey C, Azzi A (1991b) Inhibition of cell proliferation by alpha-tocopherol. Role of protein kinase CJ Biol Chem 266: 6188-6194

62. Tasinato A, Boscoboinik D, Bartoli GM, Maroni P, Azzi A (1995) D-alpha-tocopherol inhibition of vascular smooth muscle cell proliferation occurs at physiological concentrations, correlates with protein kinase $\mathrm{C}$ inhibition, and is independent of its antioxidant properties. Proc Natl Acad Sci USA 92: 12190-12194

63. Eichholzer M, Stahelin HB, Gey KF, Ludin E, Bernasconi F (1996) Prediction of male cancer mortality by plasma levels of interacting vitamins: 17-year follow-up of the prospective Basel study. Int J Cancer 66:145-150

64. Pryor AW, Cornicelli JA, Devall LJ, Tait B, Trivedi BK, Witiak DT, Wu M (1993) A rapid screening test to determine the antioxidant potencies of natural and synthetic antioxidants. J Org Chem 58: 3521-3532

65. Devaraj S, Adams-Huet B, Fuller CJ, Jialal I (1997) Dose-response comparison of RRR-alpha-tocopherol and allracemic alpha- tocopherol on LDL oxidation. Arterioscler Thromb Vasc Biol 17:2273-2279

66. Devaraj S, Jialal I (1996) Oxidized lowdensity lipoprotein and atherosclerosis. Int J Clin Lab Res 26:178-184

67. Devaraj S, Jialal I (1998) The effects of alpha-tocopherol on critical cells in atherogenesis. Curr Opin Lipidol 9: $11-15$

68. Freedman JE, Farhat JH, Loscalzo J, Keaney JF Jr (1996) Alpha-tocopherol inhibits aggregation of human platelets by a protein kinase $\mathrm{C}$-dependent mechanism. Circulation 94:2434-2440

69. Kanno T, Utsumi T, Kobuchi H, Takehara Y, Akiyama J, Yoshioka T, Horton AA, Utsumi K (1995) Inhibition of stimulus-specific neutrophil superoxide generation by alpha-tocopherol. Free Radic Res 22:431-440

70. Koya D, Lee IK, Ishii $\mathrm{H}$, Kanoh $\mathrm{H}$, King GL (1997) Prevention of glomerular dysfunction in diabetic rats by treatment with d-alpha-tocopherol. J Am Soc Nephrol 8:426-435

71. Studer RK, Craven PA, DeRubertis FR (1997) Antioxidant inhibition of protein kinase C-signaled increases in transforming growth factor-beta in mesangial cells. Metabolism 46: 918-925
72. Tada H, Ishii H, Isogai S (1997) Protective effect of D-alpha-tocopherol on the function of human mesangial cells exposed to high glucose concentrations. Metabolism 46:779-784

73. Martin-Nizard F, Boullier A, Fruchart JC, Duriez P (1998) Alpha-tocopherol but not beta-tocopherol inhibits thrombin-induced PKC activation and endothelin secretion in endothelial cells. J Cardiovasc Risk 5:339-345

74. Ricciarelli R, Tasinato A, Clement S, Ozer NK, Boscoboinik D, Azzi A (1998) Alpha-Tocopherol specifically inactivates cellular protein kinase $C$ alpha by changing its phosphorylation state. Biochem J 334:243-249

75. Clement S, Tasinato A, Boscoboinik D, Azzi A (1997) The effect of alpha-tocopherol on the synthesis, phosphorylation and activity of protein kinase $\mathrm{C}$ in smooth muscle cells after phorbol 12myristate 13-acetate down-regulation. Eur J Biochem 246:745-749

76. Neuzil J, Weber C, Kontush A (2001) The role of vitamin $\mathrm{E}$ in atherogenesis: linking the chemical, biological and clinical aspects of the disease. Atherosclerosis 157:257-283

77. Aratri E, Spycher SE, Breyer I, Azzi A (1999) Modulation of alpha-tropomyosin expression by alpha-tocopherol in rat vascular smooth muscle cells. FEBS Lett 447:91-94

78. Azzi A, Boscoboinik D, Fazzio A, Marilley D, Maroni P, Ozer NK, Spycher S, Tasinato A (1998) RRR-alpha-tocopherol regulation of gene transcription in response to the cell oxidant status. $\mathrm{Z}$ Ernahrungswiss 37:21-28

79. Ricciarelli R, Maroni P, Ozer N, Zingg JM, Azzi A (1999) Age-dependent increase of collagenase expression can be reduced by alpha-tocopherol via protein kinase $\mathrm{C}$ inhibition. Free Radic Biol Med 27:729-737

80. Shaw HM, Huang C (1998) Liver alphatocopherol transfer protein and its mRNA are differentially altered by dietary vitamin E deficiency and protein insufficiency in rats. J Nutr 128: 2348-2354

81. Febbraio M, Podrez E, Smith J, Hajjar D, Hazen S, Hoff H, Sharma K, Silverstein $\mathrm{R}$ (2000) Targeted disruption of the class B scavenger receptor CD36 protects against atherosclerotic lesion development in mice (In Process Citation). J Clin Invest 105:1049-1056

82. Devaraj S, Hugou I, Jialal I (2001) Alpha-tocopherol decreases CD36 expression in human monocyte-derived macrophages. J Lipid Res 42:521-527

83. Ricciarelli R, Zingg JM, Azzi A (2000) Vitamin $E$ reduces the uptake of oxidized LDL by inhibiting CD36 scavenger receptor expression in cultured aortic smooth muscle cells. Circulation 102:82-87
84. Teupser D, Thiery J, Seidel D (1999) Alpha-tocopherol down-regulates scavenger receptor activity in macrophages. Atherosclerosis 144:109-115

85. Islam KN, Devaraj S, Jialal I (1998) Alpha-Tocopherol enrichment of monocytes decreases agonist-induced adhesion to human endothelial cells. Circulation 98:2255-2261

86. Martin A, Foxall T, Blumberg JB, Meydani M (1997) Vitamin E inhibits lowdensity lipoprotein-induced adhesion of monocytes to human aortic endothelial cells in vitro. Arterioscler Thromb Vasc Biol 17:429-436

87. Steiner M, Li W, Ciaramella JM, Anagnostou A, Sigounas G (1997). Dl-alphatocopherol, a potent inhibitor of phorbol ester induced shape change of erythro- and megakaryoblastic leukemia cells. J Cell Physiol 172: 351-360

88. Wu D, Koga T, Martin KR, Meydani M (1999) Effect of vitamin E on human aortic endothelial cell production of chemokines and adhesion to monocytes. Atherosclerosis 147:297-307

89. Yoshikawa T, Yoshida N, Manabe H, Terasawa Y, Takemura T, Kondo M (1998) Alpha-Tocopherol protects against expression of adhesion molecules on neutrophils and endothelial cells. Biofactors 7:15-19

90. Williams JC, Forster LA, Tull SP, Wong M, Bevan RJ, Ferns GA (1997) Dietary vitamin $\mathrm{E}$ supplementation inhibits thrombin-induced platelet aggregation, but not monocyte adhesiveness, in patients with hypercholesterolaemia. Int J Exp Pathol 78:259-266

91. Saldeen T, Li D, Mehta JL (1999) Differential effects of alpha- and gamma-tocopherol on low-density lipoprotein oxidation, superoxide activity, platelet aggregation and arterial thrombogenesis. J Am Coll Cardiol 34:1208-1215

92. Iuliano L, Mauriello A, Sbarigia E, Spagnoli LG, Violi F (2000) Radiolabeled native low-density lipoprotein injected into patients with carotid stenosis accumulates in macrophages of atherosclerotic plaque: effect of vitamin E supplementation. Circulation 101:1249-1254

93. Teupser D, Stein O, Burkhardt R, Nebendahl K, Stein Y, Thiery J (1999) Scavenger receptor activity is increased in macrophages from rabbits with low atherosclerotic response: studies in normocholesterolemic high and low atherosclerotic response rabbits. Arterioscler Thromb Vasc Biol 19: 1299-1305 
94. Lee IK, Koya D, Ishi H, Kanoh H, King GL (1999) D-Alpha-tocopherol prevents the hyperglycemia induced activation of diacylglycerol (DAG)-protein kinase C (PKC) pathway in vascular smooth muscle cell by an increase of DAG kinase activity. Diabetes Res Clin Pract 45:183-190
95. Jialal I, Devaraj S, Kaul N (2001) The effect of alpha-tocopherol on monocyte proatherogenic activity. J Nutr 131: 389S-394S
96. Wu D, Hayek MG, Meydani S (2001) Vitamin E and macrophage cyclooxygenase regulation in the aged. J Nutr 131: 382S-388S 